\title{
A novel method to obtain biopsy samples from proximal biliary strictures
}

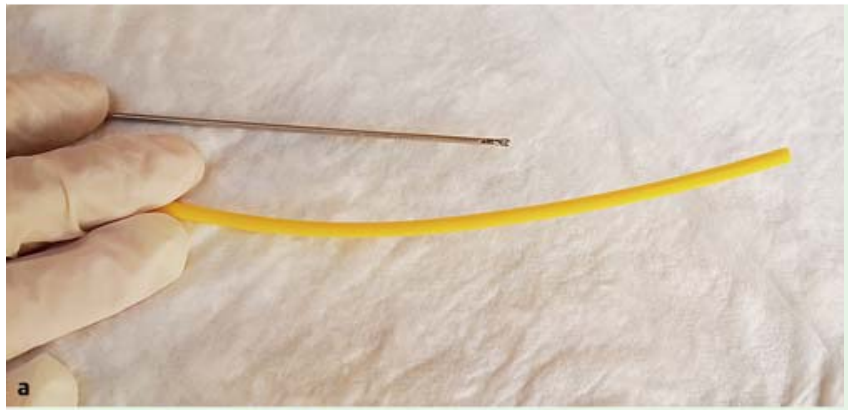

Fig. 1 a The stent pusher is $165 \mathrm{~cm}$ long whereas the biopsy forceps is $160 \mathrm{~cm}$ long. b The pusher was cut $8 \mathrm{~cm}$ from the distal end with a simple scalpel. c The final view of the biopsy forceps going out of the pusher.
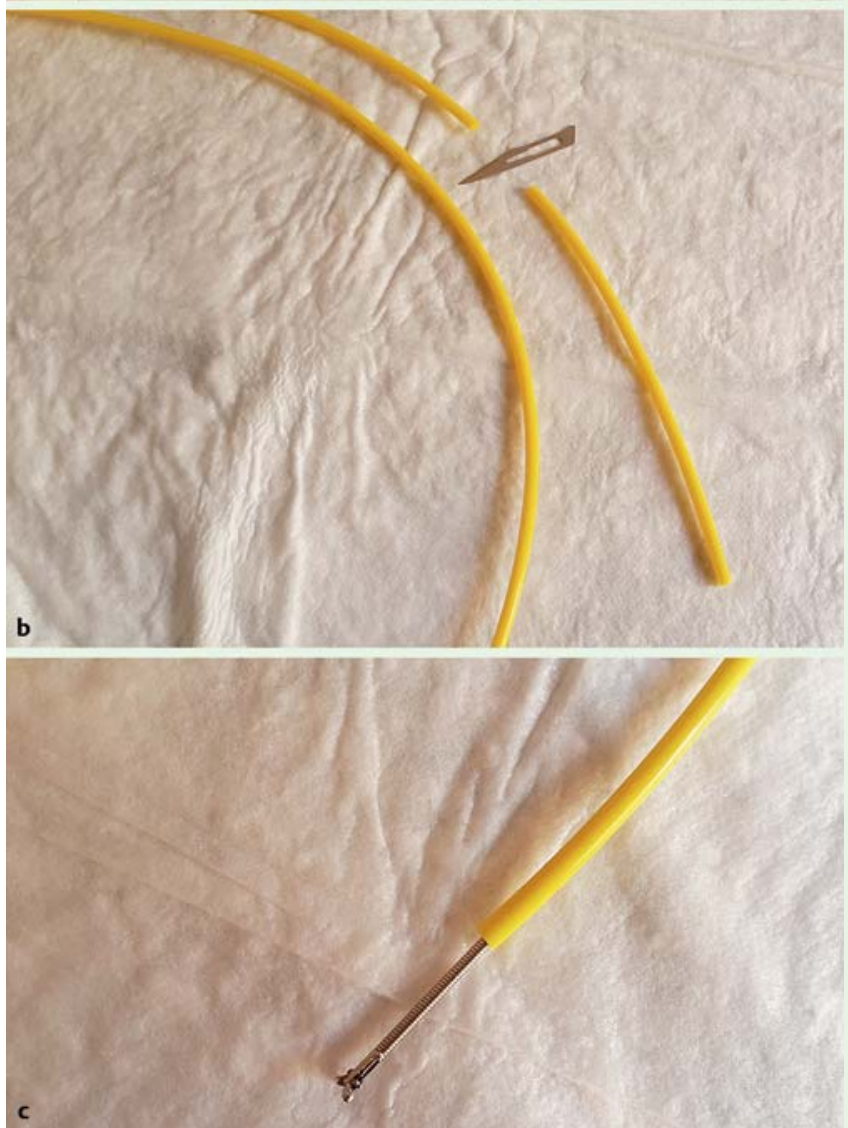
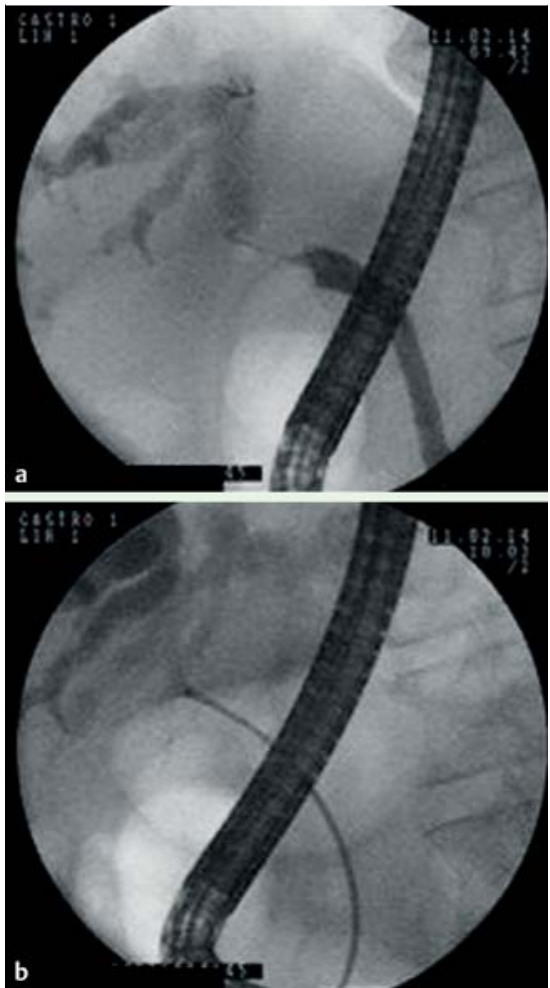

Fig. 2 a Fluoroscopic view of the proximal biliary stricture. $\mathbf{b}$ It was possible to obtain biopsy samples from the proximal stricture using a biopsy forceps advanced through the pusher.

tem for endoprostheses, diameter $2.1 \mathrm{~mm}$, length $165 \mathrm{~cm}$; MTW Endoskopie, Wesel, Germany) was cut $8 \mathrm{~cm}$ from the distal end ( $\bullet$ Fig. 1) and pushed forward over the guidewire until it reached the stricture. The guidewire was withdrawn and a biopsy forceps (diameter $1.8 \mathrm{~mm}$, length $160 \mathrm{~cm}$; Endo-Technik, Solingen, Germany) advanced through the pusher. Biopsy samples were obtained from the stricture level with the forceps ( Fig.2), and a plastic stent was subsequently placed. Histopathological examinations of the biopsy specimens in all three cases reported adenocarcinoma, whereas only one of the three brush cytology samples was reported as malignant.

A similar method using a double-balloon enteroscopy forceps has been previously reported [2]. However, the double-balloon enteroscopy forceps is more expensive and impractical than the standard biopsy forceps, and may not be available 
in many endoscopy centers. We believe that the method presented here using a biopsy forceps through a pusher can be performed advantageously to obtain adequate tissue samples from proximal biliary strictures for accurate diagnosis.

Endoscopy_UCTN_Code_TTT_1AR_2AD

Competing interests: None

\section{Fatih Tekin, Ilker Turan, Galip Ersoz, Oktay Tekesin, Omer Ozutemiz}

Department of Gastroenterology, Ege University Medical School, Izmir, Turkey

\section{References}

1 Weber A, Schmid RM, Prinz C. Diagnostic approaches for cholangiocarcinoma. World J Gastroenterol 2008; 14: 4131-4136

2 Kulaksiz H, Strnad P, Römpp A et al. A novel method of forceps biopsy improves the diagnosis of proximal biliary malignancies. Dig Dis Sci 2011; 56: 596-601

\section{Bibliography}

DoI http://dx.doi.org/ 10.1055/s-0034-1377282 Endoscopy 2014; 46: E363-E364

(c) Georg Thieme Verlag KG Stuttgart · New York ISSN 0013-726X

\section{Corresponding author} Fatih Tekin, MD

Ege Universitesi Tip Fakultesi Gastroenteroloji Bilim Dali Bornova 35100 Izmir

Turkey Fax: +90-232-3427764 drtekinfatih@gmail.com 